\title{
PELAKSANAAN SYARI'AT ISLAM DI ACEH SEBAGAI BAGIAN WILAYAH NEGARA KESATUAN REPUBLIK INDONESIA (NKRI)
}

\author{
Syamsul Bahri \\ Fakultas Hukum Universitas Syiah Kuala \\ E-mail: nyak_adek@yahoo.com
}

\begin{abstract}
The application of Sharia law is not a new thing in Indonesia, especially in Aceh. Since pre independent day of Indonesia, Aceh had been famous with its Islamic Empires, such as Samudra Pasai and Aceh Darussalam empires. Nowadays, such law is still applied by the people. However, in applying such law there are some constraints as a result of there is no fix and clear form that can be guidance in Aceh. The efforts done to find the suitable formula for such application are still conducted in every life activity that in the future might give its own characteristic in legal and political studies in Indonesia.
\end{abstract}

Key words : Sharia Law, special authonomy and Qanun

\begin{abstract}
Abstrak
Pelaksanaan Syari'at Islam bukan sesuatu yang baru dalam wilayah Negara Kesatuan Republik Indonesia, terutama di daerah Aceh. Sejak sebelum kemerdekaan Republik Indonesia, daerah Aceh sudah dikenal dengan kerajaan Islam-nya, seperti Samudera Pasai dan kerajaan Aceh Darussalam dan sampai sekarang, syariat Islam masih terus dipraktekkan oleh masyarakat Provinsi Aceh. Namun demikian, dalam proses pelaksanaannya terdapat beberapa kendala yang disebabkan secara umum karena belum adanya format baku dan jelas yang dapat dijadikan panduan pelaksanaan di Aceh. Upaya-upaya mencari bentuk format Syari' at Islam di Aceh masih terus dilakukan hingga kini dalam segala bidang kehidupan, yang nantinya memberi warna tersendiri dalam kajian hukum dan politik wilayah Negara Kesatuan Republik Indonesia.
\end{abstract}

Kata kunci : Syari'at Islam, otonomi khusus, dan Qanun

\section{Pendahuluan}

Pelaksanaan syari'at Islam di Negara Kesatuan Republik Indonesia (NKRI) tidak hanya sebagai sebuah wacana, namun sudah dipraktikkan oleh mayoritas penduduknya. Diantara daerah yang ada dalam wilayah NKRI ini adalah Aceh, yang merupakan provinsi paling barat di pulau Sumatera ini sedang menerapkan pelaksanaan syari' at Islam. Pelaksanaan syari'at Islam ini diberlakukan dan mendapat legalitas karena didukung sosio-kultural dan historis masyarakatnya, seperti Aceh dulunya dikenal sebagai pusat penyebaran agama Islam di nusantara. Namun demikian, pelaksanaan syari'at Islam tersebut tidak serta merta berjalan sesuai yang diharapkan. Ini terjadi disebabkan belum adanya rujukan yang jelas dan formulasi yang tepat dalam penerapan syari'at Islam di Provinsi Aceh, meskipun ada beberapa Negara yang menerapkan syari' at Islam bagi penduduknya.

Fenomena kebangkitan Islam yang terjadi di dunia sejak Revolusi Iran 1979, telah menjadi topik hangat di berbagai diskusi ilmiah maupun popular. Berbagai metode dan konsep diterapkan dalam rangka menyelenggarakan syari' at Islam sebagai dasar negara (khusus mayoritas Islam). Iran, Sudan dan negara Islam lainnya adalah satu contoh dari gambaran pengalaman dalam penerapan syari'at Islam di negaranya masing-masing sebagai sebuah legalitas pemerintahan.

Pro kontra selalu saja terjadi dari pengalaman negara-negara tersebut dan sampai sekarangpun masih mewarnai setiap gerak pelaksa- 
naan yang dilakukannya menyangkut Pelaksanaan Syari'at Islam. Apalagi dalam bidang hukum publik (pidana). Sehingga timbulnya anggapan dari kebanyakan tokoh Islam bahwa pengalaman-pengalaman yang terjadi di negara-negara Islam tersebut tidak dapat dijadikan cermin daIam pemberlakuan Syari' at Islam di daerah/wilayah lainnya. Namun bukan berarti mereka sepenuhnya menolak diberlakukan Syari'at Islam pada sebuah negara namun sebaliknya. Pemberlakuan itu harus tetap dilaksanakan tetapi perlu dicari konsep ideal bagaimana penerapannya sesuai dengan sosio-historis wilayah tersebut dan tentunya berdasarkan tujuan syari'at itu sendiri. Syari'at berati peraturan atau ketetapan yang Allah perintahkan kepada hamba-hambanya. Seperti shaum, shalat, haji dan seluruh kebajikan. Sebagaimana firman-Nya: Kemudian jadikan kamu berada di atas suatu syari'at (peraturan) dari urusan (agama) itu. (QS. Al-J atsiyah (45): 18). Syari' at juga dipahami sebagai sapaan ilahi. Syari'at Islam dalam pelaksanaannya mempunyai tujuan-tujuan yang harus dijaga. Ini meliputi bahwa hukum-hukum Syari'at Islam dibangun untuk kemaslahatan manusia, mencegah kerusakan dan mewujudkan kebaikan utama. ${ }^{1}$ (Allah SWT. Mengutus Muhammad Saw, sebagai rahmat bagi seluruh Alam (terdapat dalam QS. 21:107).

Pelaksanaan Syari'at Islam, sebenarnya diterapkan untuk kemaslahatan umat manusia tanpa memandang ras, golongan dan agama, namun dalam implementasinya di lapangan banyak diwarnai unsur politis. Ini bisa di lihat di berbagai negara Islam, seperti Sudan yang menjadikan Syari'at Islam sebagai alat politik penguasa yang akhirnya menjadi bumerang bagi penguasa itu sendiri. Ini menjadi salah satu alasan antipati terhadap pemberlakuan Islam sebagai sebuah syari' at yang harus ditegakkan, terutama dalam term politik. Di samping itu, Islam secara nyata sudah mengatur pelbagai persoalan dalam semua sisi kehidupan yang kesemuanya saling terkait, tidak hanya melakukan ibadah seperti dalam hal Puasa Rama-

Lihat Nur A, Fadhil Lubis, "The Child Rights in Islamic Law With A Special Focus On Aceh", Jurnal Analytical Islamica, Vol 9 No. 2 2007, hlm. 88 dhan namun juga berdampak pada prilaku manusia. Dengan kata lain, Puasa Ramadhan berdampak pada pembentukan kedisiplinan diri. ${ }^{2}$

Isu penerapan Syari' at Islam di Indonesia telah menjadi perdebatan sejak menjelang kemerdekaan Indonesia. Di antaranya tentang Piagam Jakarta dengan dihapusnya tujuh kata dari isi Piagam Jakarta tersebut. Setelah orde baru, isu ini kembali mencuat dan menjadi dilema dalam masyarakat Islam itu sendiri. Kontroversi mengenai penerapan Syari'at Islam masih berlanjut sampai sekarang ${ }^{3}$ dan masing-masing memiliki argumen yang kuat dalam mengeluarkan statemennya.

Jika dikilas balik saat penyusunan UUD, ada tiga periode yang secara jelas dikemukakan oleh Irfan Idris menyangkut kontribusi umat Islam dalam penyusunan dasar negara; yaitu pertama, dalam penyusunan UUD di masa kemerdekaan dan revolusi, partai-partai Islam menghendaki diberlakukannya Piagam Jakarta 22 J uni 1945 dengan mencantumkan tuj uh kata "dengan kewajiban menjalankan syariat Islam bagi pemeluknya". Kedua, Majelis Konstituante blok Islam kembali bertarung dengan blok Pancasila dalam perdebatan dasar dasar Negara sampai Dekrit Presiden, dan ketiga, pada amandemen UUD 1945, partai Islam kembali menuntut agar memasukkan tujuh kata dari Piagam J akarta. ${ }^{4}$

Seiring waktu di beberapa daerah di Indonesia, isu ini semakin gencar didengung-kan, diantaranya Aceh. Konflik yang terus melanda, tidak menghambat mencuatnya isu ini ke permukaan, dan akhirnya keluar UU No.18/2001, menyangkut penegakan Syari'at Islam di Aceh, dimana ketika wacana otonomi daerah sedang

Iffatin Nur, "Revitalisasi nilai-nilai Syari'ah", Jurnal Ahkam, Vol 09 No. 2 November 2007, hlm. 132

Lihat Zuhairi Misrawi, "Dekonstruksi Syari' at; J alan Menuju Desakralisasi, Reinterpretasi, Depolitisasi", dalam Tashwirul Afkar, Jurnal Refleksi Pemikiran Keagamaan dan Kebudayaan tema Deformalisasi Syari'at Islam Lembaga Kajian dan Pengembangan Sumberdaya Manusia NU dan The Asia Foundation) Jakarta, Edisi Nomor 12 Tahun 2002, hlm. 7, dan Kurniawan Zein dan Sarifuddin (ed), 2001, Syari' at Islam Yes, Syari' at Islam No, J akarta: Paramadina

4 Lihat Amrizal J. Prang dan Nanda Amalia, "Proses Pembentukan Pemerintahan Aceh", J urnal Respublica, Vol 6 No. 2 2007, Universitas Lancang Kuning Pekanbaru, hlm. 22 
berkembang di Indonesia, dan propinsi Aceh diberikan otonomi khusus oleh pemerintah Pusat. Selanjutnya lahir Undang-undang Pemerintahan Aceh Nomor 11 Tahun 2006 yang diantara pasalpasalnya secara tegas memuat pelaksanaan syari'at Islam (hukum Islam) di Provinsi Aceh secara lebih luas, salah satunya pemberlakuan hukum pidana Islam.

Setelah keluarnya legalitas Pemerintah terhadap pelaksanaan Syari'at Islam di Aceh, timbul beberapa persoalan menyangkut bagaimana penerapannya karena negara-negara Islam sebelumnya tidak dapat dijadikan acuan dalam pelaksanaannya, di antaranya salah satu sebabnya adalah sosio-kultural yang berbeda. Hingga sekarangpun belum ada contoh ideal daIam sebuah negara yang melaksanakan Syari' at Islam.

Adanya legalitas dari pemerintah untuk menerapkan syari'at Islam di Aceh, direspon oleh pemerintah daerah dengan mengeluarkan beberapa peraturan daerah (Perda) dalam rangka terlaksananya syari'at Islam di Aceh. Dari Perda-Perda ini selanjutnya dikembangkan lagi menjadi peraturan-peraturan daerah yang menyangkut tata pelaksanaan syari' at Islam, yang pada gilirannya melahirkan qanun Aceh.

Beranjak dari uraian ini pelaksanaan syaria'at Islam di Aceh dikenal dengan istilah pelaksanaan Syari'at Islam di Aceh secara Kaffah merupakan salah satu fenomena yang menarik untuk dicermati mengenai penerapannya dalam masyarakat. Tulisan ini mencoba membahas bagaimana Pelaksanaan Syari'at Islam di Aceh sebagai bagian wilayah kesatuan Republik Indonesia.

\section{Pembahasan}

\section{Lintasan Sejarah Islam di Aceh}

Sebuah kesimpulan dari para sejarawan tentang masuknya Islam pertama kali di Nusantara terjadi pada abad 1 Hijriah di Bumi Aceh. Islam dibawa oleh para pedagang Arab yang diikuti oleh orang-orang Persia dan Gujarat ke Pesisir Sumatera (Perlak atau Samudera Pasai). Diantara salah satu buktinya dengan adanya makam raja Samudera Pasai yang dikenal dengan Malik ash-Shaleh (Malikus Shaleh) (668-
1254 H/ 1289-1326 M). Pada seminar sejarah masuknya Islam ke Indonesia (di Medan, 17-20 Maret 1963) disimpulkan bahwa Islam masuk ke Indonesia pertama kali abad I Hijriah (7/8 M) langsung dari Aceh melalui pesisir Sumatera (Samudera Pasai atau Peurelak), setelah terbentuknya masyarakat Islam maka raja Islam pertama berada di Aceh dan penyiaran agama Islam di Indonesia dilakukan secara damai.

Berdasarkan catatan rihlah Ibnu Battutah, Islam masuk ke Aceh pada penghujung abad pertama Hijriah, yang di bawa oleh pedagang Arab dan India yang melakukan perdagangan di sepanjang pesisir Aceh. Penyebarannya melalui metode penetrasi damai, toleran, membangun dan berbaur dengan tradisi yang ada. ${ }^{5}$ Masuknya Islam, membawa perubahan dalam masyarakat Aceh. Nilai-nilai Islam mulai diaplikasikan dan diterapkan dalam kehidupan masyarakatnya yang sebelumnya beragama Hindu. Penerapan syari' at Islam pun mulai ada dan berkembang pada kerajaan-keraj aan Aceh, hingga puncaknya pada kesultanan Iskandar Muda (160716360). ${ }^{6}$

Hukum Islam pada masa Iskandar Muda diterapkan secara kaffah dengan mazhab Syafi'i yang meliputi bidang ibadah, ahwal al-syakhshiyyah (hukum keluarga), mu'amalat maaliyah (perdata), jinayah (pidana Islam), uqubah (hukuman), murafa'ah, iqtishadiyah (peradilan), dusturiyah (perundang-undangan), akhlaqiyyah (moralitas), dan 'alaqah dauliyah (kenegaraan). Hal ini diketahui dari adanya manuskrip-manuskrip karya Ulama Aceh, seperti karya Syekh Nuruddin Ar-Raniry, karya Abdurrauf as-Singkili dan karya-karya ulama lainnya.

Ditinjau dari historisnya, ada beberapa periode tentang perjalanan Syari'at Islam di Aceh. Rusj di mengklasifikasikan 5 periode, yaitu, pertama, syari'at Islam di masa kesultanan Aceh; kedua, di masa penjajahan Belanda; ketiga, di masa awal kemerdekaan; dan keempat di masa orde baru; serta kelima, di masa

Hasanuddin Yusuf A, "Sejarah dan Perkembangan Islam di Aceh", Jurnal Ar- Raniry, Edisi Nomor 82 Tahun 2003, hlm. 5

Lihat H.M.Syadli ZA, "Pendidikan Islam di Kesultanan Aceh: Ulama, Meunasah dan Rangkang", Jurnal al Qalam, Vol 20 No. 96 Tahun 2003, hlm. 133-139 
reformasi. Klasifikasi periode sejarah syari'at Islam di Aceh merupakan gambaran perjalanan demi sebuah legalitas dan formalisasi hukum dari pemerintah/penguasa. Semenjak runtuhnya kesultanan Aceh dan berganti dengan koIonialisme Belanda Syariat Islam di Aceh bagi masyarakatnya menjadi masa-masa sulit.

Berakhirnya penjajahan, Islam di Aceh mulai berdenyut, namun harapan itu pasca kemerdekaan hanya tinggal harapan, adanya permintaan secara legislasi yang dijanjikan Soekarno terhadap masyarakat Aceh tidak direalisasikan hingga berganti tampuk penguasa ke tangan Soeharto (Orde Baru). Soeharto merubah pola pemerintahan dan menjadikan dasar negara sebagai azas tunggal. Kebijakan-kebijakan Soeharto merugikan mayoritas masyarakat Islam di Aceh, seperti adanya aspirasi-aspirasi yang dilancarkan oleh para tokoh Aceh terhadap pelaksanaan syariat di Aceh, dijawab dengan pelaksanaan penempatan DOM di Aceh, yang pada akhirnya terjerumus pada arus politik disintegrasi bangsa. Ini menimbulkan dan memicu konflik yang berkepanjangan sampai saat ini. Ini merupakan lembaran sejarah pahit masyarakat Aceh yang notabene menginginkan pelaksanaan Syari' at Islam di daerahnya.

Akhirnya usaha untuk melaksanakan syari'at Islam di Aceh mendapat angin segar, lengsernya Soeharto yang digantikan Habibie mendapat angin segar bagi masyarakat Aceh. Respon Habibie terhadap Aceh ini menimbulkan semangat baru bagi isu-isu pelaksanaan Islam di Aceh dengan keluarnya UU No. 44 tahun 1999 tentang Pelaksanaan Keistimewaan Aceh (bidang agama, adat, pendidikan dan kebudayaan), yang dipertegas oleh UU No. 22 Tahun 1999, tentang otonomi khusus. $^{7}$ Selanjutnya dipertegas lagi, pada tanggal 9 Agustus 2001, Megawati selaku presiden menandatangani UU No.18 tahun 2001 yang dikenal dengan UU Nanggroe Aceh Darussalam. Kemudian dijabarkan dalam Perda-Perda yang dikeluarkan oleh pemerintah daerah, hingga akhirnya pelaksanaan syari'at Islam di Aceh bisa dijalankan dan

Yusni Saby, “Pelaksanaan Syari'at Islam di Aceh: Suatu Peluang dan Tantangan", J urnal Kanun, 2002, Universitas Syiah kuala Aceh, hlm, 566-568 dikenal dengan penerapan Syari' at Islam secara kaffah, dengan beberapa qanun yang telah dikeluarkannya.

Terlepas dari Perjalanan syari'at Islam di Aceh dan adanya legislasi dari pemerintahan pusat. Penerapan syariat Islam di Aceh merupakan fenomena yang menarik dicermati. Sebagaimana yang dikemukakan Daud Rasyid, bahwa bagi pemerhati hukum di Indonesia, ini merupakan peristiwa pertama setelah kemerdekaan dimana ada sebuah wilayah dalam kekuasaan hukum Indonesia menerapkan sistem hukum relatif berbeda dengan hukum nasional. ${ }^{8}$

\section{Pelaksanaan Syari'at Islam di Provinsi Aceh sebagai Bagian NKRI}

Adat bak po teumeureuhom

Hukom bak Syiah kuala

Kanun bak putroe phang

Reusam bak laksamana Artinya:

Adat ngon hukom lagee zat ngon sifeut

Adat budaya diurus oleh raja

Hukum syara' dikelola oleh ulama (syiah kuala)

Kanun diurus oleh permaisuri raja (Puteri Phang)

Reusam (tata cara kehidupan) dikelola oleh panglima

Adat dengan hukum seperti zat dengan sifat.

Ini merupakan gambaran dari kondisi sosio-kultural masyarakat Aceh, yang telah tertanam dan terpatri dari zaman ke zaman dan kerajaan Aceh Darussalam sampai saat ini. Berpijak dari Adat budaya yang searah dan relevan dengan agama, maka lahirlah untaian-untaian kata ini yang popular disebut Hadih Maja.

Pelaksanaan Syari'at Islam di Aceh sekarang ini adalah perwujudan dari cita Adagium di atas. Islam bukan hanya dipandang sebagai pedoman semata melainkan telah menjadi rutinitas dalam realitas keseharian masyarakat Aceh. Tak dapat dipungkiri bahwa masuknya budaya asing sedikit banyak mempengaruhi sosio-budaya kehidupan masyarakat Aceh nanti-

Daud Rasyid, 2001, Formalisasi Syari'at di Serambi Mekkah, dalam buku Syari'at Islam Yes, Syari'at Islam No, Jakarta: Paramadina, hlm, 217 
nya. Dikatakan pelaksanaan secara Kaffah, karena Syari'at Islam itu dilaksanakan tidak sebatas bidang ibadah saja, tetapi secara menyeIuruh mencakup semua bidang, seperti Mu'amalah hingga persoalan "Uqubah (hukuman). Dengan melihat dari masa lalu yang pernah diterapkan pada masa kesultanan Islam di Aceh (Iskandar Muda).

Upaya-upaya penerapan syariat Islam meIalui hukum negara sebenarnya telah dilakukan di indonesia secara bertahap sejak puluhan tahun yang lalu dengan cara mengadopsi hukum Islam ke dalam hukum negara. Hal ini dapat dilihat dengan adanya Undang-undang Nomor 1 Tahun 1974 tentang Perkawinan yang secara umum oleh sebagian orang dipandang sebagai hukum munakahat Indonesia, karena menurut undang-undang tersebut, seorang muslim tidak mungkin menikah di luar hukum pernikahan Islam. ${ }^{9}$

Keluarnya UU No.22 tahun 1999, UU No. 44 tahun 1999 tentang Keistimewaan Aceh dan dipertegas UU No. 18 tahun 2001 tentang Otonomi Khusus, diantaranya bertujuan melaksanakan dan mengembangkan Syari'at Islam di Provinsi Aceh. Legislasi dari pemerintah pusat terhadap Syari' at Islam di Aceh, tidak diperoleh secara singkat tetapi kerap diwarnai lika-liku perjalanan politik yang panjang. Di samping itu, adanya legalitas pelaksanaan syari'at Islam di Indonesia tidak lepas dari situasi dan kondisi politik pada waktu itu seperti pernyataan yang dikemukakan oleh Ridwan al Makassary yaitu usaha implementasi syari'at Islam tidak dapat dielakkan dari momentum reformasi yang telah menerbitkan liberalisasi politik dan meretas ruang kesempatan bagi kalangan fundamentalis. Beberapa daerah yang menyikapi kondisi ini dengan mempraktekkan gagasan ini antara lain Aceh, Banten, Tasikmalaya, Makassar dan lainnya. ${ }^{10}$

9 Armia Ibrahim, Peraturan Perundang-undangan Tentang Pelaksanaan Syari'at Islam di Aceh, www. Mahkamahsyariahaceh.go.id.

10 Ridwan al-Makassary, "Perda Syari'at Islam dan Implikasinya Terhadap Kebebasan Sipil, Non Muslim dan Perempuan (Studi Kasus Tasikmalaya)", J urnal Respublica Vol 6 No. 1 Tahun 2006, Universitas Lancang Kuning Pekanbaru, hlm. 210
Pemerintah daerah merespon undangundang tersebut dengan mengeluarkan Perda (peraturan daerah) untuk mengatur proses pelaksanaan Syari'at Islam secara kaffah di Provinsi Aceh. Perda-perda tersebut antara lain: Peraturan Daerah No. 3/2000 tentang Majelis Permusyawaratan Ulama (MPU); Peraturan Daerah No. 5/2000 tentang Pelaksanaan Syari'at Islam; Peraturan Daerah No. 6/2000 tentang Penyelenggaraan Pendidikan; Peraturan Daerah No. 7/2000 tentang Penyelenggaraan Kehidupan Adat; Qanun Provinsi NAD No. 12/2003 tentang Minuman Khamar dan sejenisnya; Qanun Provinsi NAD No. 13/2003 tentang Maisir; dan Qanun Provinsi NAD No. 14/2003 tentang Khalwat (Mesum). ${ }^{11}$ Ini menjadi fenomena yang menarik sekaligus menantang untuk dicermati, terutama menyangkut kesiapan pemerintah Aceh dan masyarakatnya dalam menerima dan menjalankan Syari'at Islam secara kaffah. Kontroversipun muncul tidak hanya di kalangan Aceh sendiri tetapi meluas keberbagai daerah di Nusantara dalam menyikapi persoalan jalannya pelaksanaan Syari'at Islam di Aceh secara kaffah.

Pelaksanaan Syari'at Islam di Aceh ini bagi pemerhati hukum nasional menyebutkan sebagai peristiwa pertama setelah kemerdekaan, di mana ada sebuah wilayah dalam kekuasaan Indonesia menerapkan sistem hukum yang relatif berbeda dengan hukum Nasional. Konsekuensinya adalah klaim untuk menentukan suatu kawasan wilayah Islam dengan formalisasi syari'at sebagai hukum positif adalah sebuah kontradiksi.

Munculnya kontradiksi dan kontroversi menyangkut formalisasi syari'at Islam dalam kawasan hukum positif adalah lumrah terjadi, dan ini terjadi tidak hanya di Aceh, tetapi menjadi isu nasional yang mencuat di daerahdaerah yang coba mempraktekkan Syari'at Islam di wilayahnya. ${ }^{12}$ Terlepas dari perdebatan

11 Lihat Dinas Syari'at Islam Provinsi Nanggroe Aceh Darussalam, 2005, Himpunan Undang-Undang, Keppres, Perda Qanun, Instruksi Gubernur, Edaran Gubernur Berkaitan Pelaksanaan Syari'at Islam, Banda Aceh: Dinas Syari' at Islam Provinsi Nanggroe Aceh Darussalam

12 Haidlor Ali Ahmad, "Penerapan Syari' at Islam dan Awigawig di Indonesia: Studi Perbandingan", Harmoni J urnal 
yang ada, tataran syari' at Islam yang akan dijalankan di Aceh tetap berada dalam kerangkakerangka hukum yang berlaku di Indonesia.

Mencermati keberadaan hukum Islam dalam perundang-undangan yang berlaku di Indonesia, Ali Imron mengklasifikasikan tiga bentuk yaitu pertama, hukum Islam menjadi hukum nasional dalam bentuknya yang utuh seperti dalam kitab-kitab figh; kedua, hukum Islam dalam bentuk yang sudah ada modifikasi atau penyesuaian perkembangan dinamika sosial masyarakat Indonesia; dan ketiga, materi dapat diterima sebagai fiqh bila terdapat banyak nilai kemashlahatan dan ttidak ada benturan dengan dalil yang ada. ${ }^{13}$

Al Yasa' Abu Bakar mengatakan pelaksanaan syari'at Islam di Aceh masih trial and error (coba-coba salah). ${ }^{14}$ J adi masih diperlukan masukan-masukan dari berbagai pihak dalam proses pelaksanaan syari'at Islam di Aceh ini. menyangkut ini Azra dalam tulisannya menyebutkan salah satu problem pelaksanaan syari' at Islam di Aceh karena belum adanya negara sebagai acuan pelaksanaan Syari'at Islam. ${ }^{15}$

Terlepas dari perdebatan dan kontroversi menyangkut pelaksanaan syari'at Islam di Aceh. Pemerintah daerah Aceh telah mensosialisasikan penerapan syari'at Islam ke berbagai pelosok dan masyarakat menanggapinya dengan berbagai cara. Masyarakat berharap dengan adanya penerapan syari'at tersebut mampu mengatasi semua problem yang sedang berkecamuk di Aceh.

Salah satu yang menjadi ciri khas propinsi Aceh dalam rangka keluarnya UU No.18/2001 adalah Mahkamah Syar'iyah dan penyelenggaran kehidupan adat dalam kerangka Negara Kesatuan Republik Indonesia. Dengan ini peme-

Multikultural \& Religius, Vol IV No. 15 Tahun 2005, hlm. 135-140

13 Ali Imron, "Problematika Implementasi Hukum Islam di Indonesia", Jurnal Masalah-Masalah Hukum, Vol 37 No. 1 Maret 2008, Universitas Diponegoro Semarang, $\mathrm{hlm}$. 44

14 Lihat tulisan Al Yasa' Abu Bakar, 2002, Pelaksanaan Syari'at Islam di Aceh (Sejarah dan Prospek) dalam buku Syariat di Wilayah Syari'at, Aceh: Dinas syari'at Islam, hlm. 45

15 Azyumardi Azra, 2001, Belum Ada Negara Sebagai Acuan Pelaksanaan Syari'at Islam dalam Kurniawan dkk (ed), op.cit, hlm.183-191 rintah mengatasi otonomi khusus Aceh berdasarkan ketetapan MPR menyatakan bahwa, pertama, mempertahankan integrasi bangsa daIam wadah Negara Kesatuan Republik Indonesia dengan menghargai kesetaraan dan keberagaman kehidupan sosial budaya masyarakat Aceh, melalui penetapan Daerah Istimewa Aceh sebagai otonomi khusus yang diatur dengan UU; kedua, menyelesaikan kasus Aceh secara berkeadilan dan bermartabat dengan melakukan pengusutan dan pengadilan yang jujur bagi pelanggar HAM, baik selama pemberlakuan DOM maupun pasca DOM.

Menyangkut Mahkamah Syar'iyah, terlihat pada beberapa pasal dalam Undang-undang Provinsi Aceh, seperti Pasal 1 ayat (7) yang menentukan bahwa Mahkamah Syar'iyah Propinsi Aceh adalah lembaga peradilan yang bebas dari pengaruh pihak manapun dalam wilayah provinsi Aceh yang berlaku untuk pemeluk agama Islam. Selanjutnya pasal 25 ayat (1),(2) dan (3) menentukan: pertama, Peradilan Syari' at Islam di propinsi Aceh sebagai bagian dari sistem peradilan nasional yang dilakukan oleh Mahkamah Syar' iyyah yang bebas dari pihak manapun; kedua, Kewenangan Mahkamah Syar'iyah sebagaimana dimaksud pada ayat 1 , didasarkan atas Syari'at Islam dalam sistem hukum nasional, yang diatur lebih lanjut dengan Qanun propinsi Aceh; dan ketiga, Kewenangan sebagaimana dimaksud pada ayat (2) diberlakukan bagi pemeluk agama Islam.

Meskipun Mahkamah Syar'iyah telah terbentuk dan merupakan lembaga baru namun tetap berda di bawah induknya yaitu Mahkamah Agung dan penegakan hukum Islam masih dalam konteks sistem hukum nasional, yang juga nantinya memunculkan kontroversi-kontroversi lagi. Mengenai kewenangannya sebagaimana yang diutarakan Rusjdi mengenai kewenangan Mahkamah ini disebutkan didasarkan atas Syari'at Islam dalam sistem hukum nasional yang diatur lebih lanjut dengan qanun propinsi Aceh. Dalam hal ini sebenarnya kita masih merabaraba tentang kewenangan Mahkamah Syar'iyah ini yang lebih luas daripada peradilan Agama 
sebelumnya. ${ }^{16}$ Tingkatan Mahkamah Syar'iyah ada dua di propinsi, Tingkat pertama ada di Kabupaten/ Kota dan Tingkat Banding ada di Ibukota propinsi Aceh, sedangkan kasasi ada tetap berada pada Mahkamah Agung RI di J akarta.

Seiring dengan Mahkamah Syar'iyah, dibentuklah lembaga pengawas syari'at Islam, dikenal dengan polisi syari'at atau juga wilayat al-hisbah. Mereka bertugas mengawasi jalannya pelaksanaan syari' at Islam di Aceh dan bila terjadi pelanggaran, maka akan dilakukan penindakan. Setelah lembaga ini terbentuk, mereka sering melakukan razia-razia, seperti razia terhadap pemakaian busana dan lainnya (pada gilirannya menimbulkan berbagai kontroversi terhadap mereka).

Sosialisasi syari'at dan pengawasan yang mereka lakukan ini berdasarkan qanun yang telah dibuat seperti mengenai khamar, khalwat dan lainnya. Operasi-operasi yang dilakukan lembaga ini, biasanya bekerjasama dengan aparat kepolisian daerah. Jika kedapatan melanggar maka akan diproses, namun sebelumnya diberi peringatan terlebih dahulu (biasanya bagi yang tidak memakai busana muslim bagi yang muslim).

Qanun mengenai tata pelaksanaan syari'at Islam telah berhasil dibentuk sepanjang 2002 hingga akhir 2003 oleh MPU dan kemudian ditetapkan serta diundangkan oleh DPRD Provinsi Aceh. Qanun-qanun tersebut antara lain: Qanun No. 10 Tahun 2002 tentang Peradilan Syari'at Islam; Qanun No.11 Tahun 2002 tentang Pelaksanaan Syari' at Islam bidang Aqidah, Ibadah dan Syiar Islam; Qanun No.12 Tahun 2003 tentang Larangan minuman Khamar dan sejenisnya; Qanun no.13 Tahun 2003 tentang Maisir (Perjudian); dan Qanun no.14 Tahun 2003 tentang Khalwat (Mesum) dan qanun lainnya.

Rusjdi menuliskan wilayah hisbah adalah suatu lembaga yang bertugas menegakkan amar makruf dan mencegah nahi mungkar serta bertujuan untuk menjaga ketertiban umum, memelihara keutamaan moral dan adab dalam

16 Basiq Djalil, 2010, Peradilan Agama di Indonesia, J akarta: Kencana, hlm. 181 masyarakat. ${ }^{17}$ Pasca tsunami 2004, Aceh kembali mencoba menerapkan Syari'at Islam. Petugas hisbahpun sering melakukan operasi di kamp-kamp pengungsian dan tempat-tempat lainnya. Di daerah yang agak normal, seperti di Bireun pelaksanaan tugas petugas ini lebih optimal, mereka menangkap beberapa orang yang melanggar qanun Aceh, seperti menyangkut kasus hukum pidana Islam dengan jalan pencambukan terhadap mereka (penjudi dan pemabuk yang ditangkap dan telah diproses) yang dilakukan oleh petugas syari' at dan disaksikan masyarakat umum. Ini merupakan sejarah pertama di Indonesia. Dalam peristiwa ini kontroversi dan bahkan kecaman pun berdatangan menyikapi pelaksanaan hukuman cambuk bagi mereka yang melanggar syari'at Islam (sebagaimana terlampir dalam qanun), dengan alasan diantaranya tidak sesuai dengan HAM atau lainnya.

Al Yasa' Abu Bakar memandang bahwa hukuman cambuk layak direkomendasikan masuk dalam RUUHP, paling tidak sebagai hukuman alternatif disamakan dengan penjara atau denda. Pandangan ini didasari bahwa hukuman cambuk dianggap relatif sesuai dengan budaya dan rasa keadilan masyarakat, dalam arti lebih menjerakan dan lebih menakutkan. Setidaknya sebagian masyarakat tidak merasa takut dengan hukuman penjara, tetapi sangat takut dengan hukuman cambuk. Mengenai formula atau kesebandingannya dapat disesuaikan dengan aturan yang sudah ada, misalnya hukuman cambuk tertinggi adalah 100 kali disamakan dengan hukuman penjara tertinggi yaitu 20 tahun penjara dan hukuman denda tertinggi tiga ratus juta rupiah. Mengikuti jalan pikiran ini, maka satu kali cambuk dapat disamakan dengan dua bulan penjara atau denda kategori satu. ${ }^{18}$

Terlepas dari persoalan cambuk di Aceh, pelaksanaan Syari'at Islam di Aceh menuai kebingungan dalam penerapan sistem hukum yang ada di Indonesia. Pernyataan semisal ini diung-

17 Rusjdi Ali Muhammad, 2003, Revitalisasi Syari'at di Aceh, J akarta: Logos, hlm. 187

18 Al Yasa' Abubakar, 2005, Bunga Rampai Pelaksanaan Syari'at Islam (Pendukung Qanun Pelaksanaan Syari' at Islam), Aceh: Dinas Syari'at Islam Provinsi Nanggroe Aceh Darussalam, hlm. 99 
kapkan oleh beberapa LSM seperti Kontras dan beberapa tokoh ormas seperti NU. Hasyim Muzadi misalnya, bahkan telah mempertanyakan kepada MPR, DPR dan pemerintah, mengapa NKRI bisa ada dua sistem hukum yang berbeda seperti di Aceh. Bahkan menurutnya, dalam suatu negara kesatuan dan bahkan juga federal, hukum lokal (kabupaten, provinsi, atau negara bagian), tidak boleh bertentangan secara diametral dengan konstitusi yang berskala nasional. Dalam beberapa tulisan yang muncul di harian juga menyatakan hal serupa. Penerapan hukum agama dalam perundangan daerah bertentangan dengan konstitusi yang tidak berdasarkan pada hukum agama. Konstitusi menjamin kebebasan beragama. Sebab itu penerapan Syari' at Islam dengan sanksi hukum negara tidak syah! Peraturan daerah itu harus dicabut, yaitu Qanun (Peraturan Daerah) Provinsi Nanggroe Aceh Darussalam Nomor 13 Tahun 2003 tentang Maisir (Perjudian) yang merupakan pelaksanaan Syari'at Islam, dan UU No 18 Tahun 2001 tentang Provinsi NAD, sekurang-kurangnya Pasal 25, Ayat (1) yang menyebutkan bahwa peradilan syari' at Islam di Provinsi Aceh sebagai bagian dari sistem peradilan nasional dilakukan oleh Mahkamah Syari' at yang bebas dari pihak mana pun, harus dinyatakan inkonstitusional dan dicabut.

Pernyataan semacam itu adalah wajar karena memang dalam studi hukum kita mengenal bahwa hukum yang di berada pada level bawah tidak dapat bertentangan dengan hukum yang berada pada level di atasnya. Kaedah ini barangkali merupakan kaedah yang umum diketahui oleh masyarakat banyak. Tetapi juga dalam kajian hukum ditemukan kaidah lain yang tidak banyak diketahui masyarakat secara luas, yaitu kaidah lex specialis derogat lex generalis yang bermakna aturan hukum yang khusus dapat mengenyampingkan aturan hukum yang berlaku umum.

Pelaksanaan Syari'at Islam secara kaffah di Aceh masih mencari format yang tepat dalam penerapannya. Ini disebabkan berbagai kendala/ hambatan yang tidak bisa ditutupi begitu saja, seperti konflik dan lainnya. Muslim Ibrahim menyatakan pelaksanaan syari' at seca- ra kaffah pasti akan berhadapan dengan sejumlah hambatan, faktor tersebut berupa: pertama, situasi Aceh yang masih belum kondusif, namun demikian agaknya upaya ke arah penerapannya wajib terus dilaksanakan, karena pelaksanaan syari'at itu sendiri, bila dilaksanakan dengan ikhlas mudah-mudahan dapat dijadikan sekelumit penawar bagi kondisifitas keadaan di Aceh; dan kedua, perangkat lunak berupa materi dan panduan penerapan belum semuanya mungkin sampai ratusan qanun terumus secara amat rinci. ${ }^{19}$ Dampak lain juga muncul terhadap implementasi qanun yang sudah jadi, yaitu belum adanya hukum acara bagi pelanggar qanun yang akan diproses secara hukum yang terjadi di Aceh khususnya dalam hukum pidana. ${ }^{20}$

Pemberlakuan dan penerapan syari'at Islam di Aceh dalam kerangka wilayah Republik Indonesia merupakan satu contoh yang dijadikan patokan oleh wilayah lainnya di Indonesia yang juga menginginkan berlakunya hukum Islam di Indonesia. Oleh sebab itu wajar jika semua mata mengarah dalam mengamati Aceh dengan praktek hukum Islam yang diterapkannya. Diantara sorotan yang menjadi alasan perdebatan yaitu karena adanya pluralitas keberagamaan di Indonesia seperti tertuang dalam sila pertama Pancasila. ${ }^{21}$

Terlepas dari sorotan tersebut, keinginan pemberlakuan hukum Islam di Indonesia tidak hanya untuk daerah Aceh saja tapi daerahdaerah yang ada dalam wilayah NKRI, karena pada kenyataannya persentase penduduk Indonesia mayoritasnya beragama Islam. Selain itu, keberadaan hukum Islam di Indonesia dalam sebuah legislasi dapat menunjang penegakan hukum di Indonesia. Ini disebabkan adanya proses transformasi nilai-nilai ajaran Islam dalam sikap

19 Muslim Ibrahim, 2004, Syari'at Islam di Aceh, Seminar tahunan UIN/ STAIN selndonesia yang dilaksanakan pada bulan Desember Tahun 2004 di Aceh, hlm. 8

20 Lihat Analiansyah, "Qanun Hukum Acara J inayat Dalam Pelaksanaan Syari' at Islam (Studi Terhadap Draft Qanun Hukum Acara J inayat di Aceh)", J urnal Legitimasi, Vol I Tahun 2011

21 Lihat Bani Syarif Maula, "Realitas Hukum Islam dalam Konfigurasi Sosial Politik di Indonesia (Perspektif Sosiologi Hukum Tentang Perkembangan Hukum Islam di Indonesia)", Hermenia Jurnal Kajian Islam Interdisipliner, Vol. 2 No. 2 Tahun 2003 
hidup kesehariannya dalam bertindak adil dan benar. ${ }^{22}$

Ditinjau dari berbagai sudut, sebenarnya pelaksanaan syari'at Islam di Aceh secara kaffah merupakan satu persoalan yang tidak mudah (tidak semudah membalik telapak tangan). Hal itu diperlukan masukan-masukan dan tahapan-tahapan yang harus dijalankan, di samping harus menyesuaikan dengan kondisi sosiokultural masyarakat Aceh itu sendiri. Bagaimana bentuk yang harus dilakukan dan bagaimana konsep yang sesuai dilaksanakan dalam realitasnya hingga saat ini masih dicari formatnya. Agar masyarakat dan pelaksanaan syari'at itu mudah diterima dalam semua dimensi kehidupan dan berjalan seiring dengan perkembangan masyarakat Aceh hari ini serta esok.

\section{Penutup}

Pelaksanaan Syari'at Islam di Negara Kesatuan Republik Indonesia bukan sesuatu yang baru. Hal ini beranjak dari praktek-praktek keseharian masyarakat Indonesia yang mayoritasnya beragama Islam. Meskipun dalam kesehariannya, penduduk Indonesia menerapkan ajaran Islam secara individuallistis, namun dalam beberapa aspek yang berkaitan dengan kolektivitas masyarakat seperti bidang hukum, kenegaraan dan lainnya, Negara Indonesia memiliki falsafah tersendiri yaitu Pancasila, sebab penduduk di Indonesia yang tersebar di berbagai pulau memiliki beragam etnis dan budaya serta agama yang berbeda-beda.

Salah satu diantaranya adalah daerah Aceh yang hampir seluruh penduduknya beragama muslim dan bahkan dalam praktek kesehariannya menerapkan ajaran Islam dalam seluruh aspek kehidupan. Setelah melewati proses yang panjang, pada akhirnya Aceh menjadi satusatunya daerah yang ada di Indonesia yang memiliki legalitas dalam pelaksanaan Syari'at Islam secara lebih luas, yang tentunya berdasarkan Undang-Undang Pemerintahan Aceh Nomor 11 Tahun 2006.

22 M, Arifin Hamid, "Internalisasi Wawasan Keislaman Menuju Efektifitas Penegakan Hukum di Indonesia", Majalah IImiah Hukum Amanna Gappa Universitas Hassanudin Makassar, Vol 13 No. xi Tahun 2003, hlm. 369
Pelaksanaan syari'at Islam di Aceh masih dalam pencarian formatnya meskipun penerapannya telah dilaksanakan, apalagi pasca tsunami. Hancurnya berbagai sektor kehidupan merupakan satu faktor penghambat dalam pelaksanaan itu sendiri, namun tidak semuanya terlena dengan musibah ini. Di Bireuen (salah satu kota di Aceh yang tidak terkena tsunami) mencoba menjalankan syari'at Islam secara kaffah (termasuk hukum pidana), mereka (polisi syari'at) berhasil menangkap para pemabuk dan penjudi yang kemudian diproses dan diadili sesuai dengan perbuatan yang mereka lakukan. Namun di balik itu semua, masukan-masukan dan kritikan dengan sebuah solusi, sebenarnya sangat dibutuhkan untuk tercapainya pelaksanaan syari' at Islam di Aceh yang harmonis.

\section{Daftar Pustaka}

Abu Bakar, Al Yasa'. 2005. Bunga Rampai Pelaksanaan Syari'at Islam (Pendukung Qanun Pelaksanaan Syari' at Islam). Aceh: Dinas Syari'at Islam Provinsi Nanggroe Aceh Darussalam;

Adan, Hasanuddin Yusuf. "Sejarah dan Perkembangan Islam di Aceh". J urnal ArRaniry, Nomor 82 Tahun 2003;

Ahmad, Haidlor Ali. "Penerapan Syari' at Islam dan Awig-awig di Indonesia: Studi Perbandingan". Harmoni Jurnal Multikultural \& Religius, Vol IV No. 15 Tahun 2005;

Al-Makassary, Ridwan. "Perda Syari'at Islam dan Implikasinya Terhadap Kebebasan Sipil, Non Muslim dan Perempuan (Studi Kasus Tasikmalaya)". J urnal Respublica, Vol 6 No. 1 Tahun 2006. Universitas Lancang Kuning Pekanbaru;

Analiansyah. "Qanun Hukum Acara J inayat Dalam Pelaksanaan Syari'at Islam (Studi Terhadap Draft Qanun Hukum Acara J inayat di Aceh". J urnal Legitimasi, Vol I Tahun 2011;

Dinas Syari'at Islam Provinsi Nanggroe Aceh Darussalam. 2002. Syari'at di Wilayah Syari'at. Aceh: Dinas Syari'at Islam Provinsi Nanggroe Aceh Darussalam;

Djalil, Basiq. 2010. Peradilan Agama di Indonesia. J akarta: Kencana

Hamid, M. Arifin. "Internalisasi Wawasan Keislaman Menuju Efektifitas Penegakan 
Hukum di Indonesia". Majalah IImiah Hukum Amanna Gappa Vol 13 No. XI Tahun 2003. Universitas Hassanudin Makassar;

Ibrahim, Muslim. 2004. Syari'at Islam di Aceh. Seminar tahunan UIN/ STAIN se-Indonesia yang dilaksanakan pada bulan Desember Tahun 2004 di Aceh;

Imron, Ali. "Problematika Implementasi Hukum Islam di Indonesia". Jurnal MasalahMasalah Hukum, Vol 37 No. 1 Maret 2008, Universitas Diponegoro Semarang;

Lubis, Nur A. Fadhil. "The Child Rights in Islamic Law With A Special Focus On Aceh". Jurnal Analytical Islamica, Vol 9 No. 2 Tahun 2007;

Maula, Bani Syarif. "Realitas Hukum Islam dalam Konfigurasi Sosial Politik di Indonesia (Perspektif Sosiologi Hukum Tentang Perkembangan Hukum Islam di Indonesia)". Hermenia Jurnal Kajian Islam Interdisipliner, Vol 2 No. 2 Tahun 2003;

Misrawi, Zuhairi. "Dekonstruksi Syari'at; Jalan Menuju Desakralisasi, Reinterpretasi, De- politisasi", dalam Tashwirul Afkar". Jurnal Refleksi Pemikiran Keagamaan dan Kebudayaan, Edisi nomor 12 Tahun 2002;

Muhammad, Rusjdi Ali. 2003. Revitalisasi Syari' at Islam di Aceh. J akarta: Logos;

Nur, Iffatin. "Revitalisasi Nilai-Nilai Syari'ah". J urnal Ahkam, Vol 09 No. 2 November 2007;

Prang, Amrizal J. dan Nanda Amalia. "Proses Pembentukan Pemerintahan Aceh". J urnal Respublica, Vol 6 No. 2 Tahun 2007 Universitas Lancang Kuning Pekanbaru;

Saby, Yusni. "Pelaksanaan Syari'at Islam di Aceh: Suatu Peluang dan Tantangan". Jurnal Kanun, 2002. Universitas Syiah Kuala Aceh;

ZA, H.M. Syadli. "Pendidikan Islam di Kesultanan Aceh: Ulama, Meunasah dan Rangkang". Jurnal al Qalam, Vol 20 No. 96 Tahun 2003;

Zein, Kurniawan dan Sarifuddin (ed). 2001. Syari'at Islam Yes, Syari'at Islam No. J akarta: Paramadina. 